\title{
Impact of Time Management on Organizational Effectiveness
}

\author{
Article by James Ziekye \\ PhD in Management, Texila American University, Guyana \\ Email: jamesziekye@yahoo.com
}

\begin{abstract}
Future Implications: The study focuses on the practice and observance of the three central factors, planning/scheduling, organizing/prioritizing and personal Purpose: within the context of the current level of globalization and its associated technological advancement, coupled with the ever increasing global business competiveness, time management is regarded as one of the most effective management principles requiring the recognition of effective factors on reactions to stressful events undertaken by employees and staff of many organizations which desire to scale the pinnacle of success. The purpose of this paper is to determine and identify the factors that affect time management in Ghana and examining the relationship between organizational effectiveness and time management.

Approach: A model was designed based on the literature, linking factors of time management with time management and organizational effectiveness. Four hypotheses were built based on the literature and the model were tested in perspective of the previous studies and literature.

Findings: The literature and various studies concluded that factors such as strategic planning, organizing/prioritizing and personal responsibility / accountability as principal indices of time management cumulatively have positive impact on organizational effective performance. The more these important time management principles or indices are employed by any organization or management, the more efficient and effective their time management practice becomes. Also there exists a positive relationship between time management and organizational

Effectiveness. The more efficiently time is managed by the staff and employees of an organization, the more productive and effective the organization becomes.

Responsibility/discipline for enhancing institutional time management which leads to productivity and organizational effectiveness. The organizations should therefore design their rules, processes, policies and organizational structures in such a manner that gives room for the implementation and operationalization of among other factors, these three fundamental imperatives. This will surely lead to organizational growth and development.
\end{abstract}

Keywords: Time management, impact and organizational effectiveness

\section{Introduction}

The main purpose of this article is to propose or recommend by pointing out the critical pillars/ factors as well as the new possibilities of time management and its impact on productivity and organizational effectiveness. It is fundamentally aimed at shedding light on how an organization through its time management policies, processes and principles such as planning, organizing, scheduling, prioritizing, personal responsibility/discipline can achieve success and growth for the organization as a whole. This would undoubtedly enable employees to use their time more effectively for the much needed better services and better customer satisfaction whether in the public or private sector organization.

Time management has become a critical factor for most government organizations in Africa and Ghana in particular, which has, in recent times, been bedeviled with outrageous public sector wage bills with very little to show for it in terms of productivity, good customer service and actual value for money, as a result of which many are calling for public sector reforms. One of the main reasons for the continuing underdevelopment of African countries is 
our nonchalant attitude to time and the need for punctuality in all aspects of life. The problem of punctuality has become so endemic that lateness to any functions is accepted and explained off as 'African time'. It is against this background that time management in public administration or private sector organization in Ghana is so crucial.

Time, as a key critical resource in every organization must be managed carefully and judiciously because of its limitations, impermanence and non-recoverable character, in order to maximize productivity and better customer services. The new possibilities of time management presented in this paper can help policy makers, managers and public administrators to adopt and implement right strategies that would bring about the much needed positive transformation in their organization.

After all, given the opportunity without time as limiting factor, everyone is able to do their job, unfortunately however time is of essence here and their abilities are measured by how much time they require to do it.

\section{Literature review}

\section{Time management}

\section{Time}

Under the term time management we mean organization, distribution and duration of work indifferent periods such as day, week, month, or year. What is time? Some even say that time does not exist because the past is unreachable, the future is unknown, and the present is immeasurable, which is an interesting theory. We will allocate a simplified definition of time which says that time is actually movement in space.

It can also be explained as a period of time considered as resources under your control and sufficient to accomplish a given activity task. It is the period during which actions or processes take place-Webster's Collins dictionary calls time as a system or measuring duration. A scarce resources which must be properly and sagaciously managed otherwise nothing can be managed [27]. The continuum of experience in which events pass from the future through the present to the pass [30].

The supply of time is very limited, while the demand for it is limitless. Time is life. To waste your time therefore is to have wasted one's life.

\section{Attributes of time}

Time is a unique and one most scarce resource in the universe. It can neither be replaced like man nor accumulated like money. Time cannot be turned on and off like a machine or stock piled like raw materials. It flows at a pre-determined rate whatever happens and everybody is equally endowed with the same amount of it irrespective of his position, hence, time like any other scarce resource must be managed and used judiciously.

\section{Time management}

Reed defined management as the organizational process that includes managing resources, strategic planning, setting; objectives, employing and deploying the financial and human assets needed to achieve objectives, and measuring results [28]. As defined by [31], time management is basically the art of arranging business and personal affairs in such a way that you together with your things show up when, where, and how you have intended them to as effortlessly and ubiquitously, as practicable, and to facilitate getting things done as promptly as practicable with the less amount of resources (money, time, energy and people) necessary.

Time management actually represents the tool, skills and abilities required in doing the right thing at the right time, with minimum effort, and resources, effectively and efficiently, leading to the achievement of your goals and the things you personally prioritized and value.

Time management according to North [29] is the organization of tasks or events by first estimating and forecasting how much a task would take to be completed, when exactly it must be completed and adjusting events that would interfere with its completion, so that 
completion is finally reached in the appropriate anticipated amount of time. Time management is not about getting more things done in a day. It is rather about getting the things that matter most done. It is the ability to responsibly decide what is important in life both at work, at home and even one's personal life.

Time management is not and would not ever be distinct and separable from management in general. Its main objective is to prevent dawdling and waste of time and regulate working time. Time management places much emphasis on preventing unnecessary activities, increase of efficiency, organizing and delegating tasks.

Effective time management provides employees with a feeling of greater security, independence and the clients with satisfaction with efficient and faster service delivery tailored to the needs.

According to Crutsinger [2], time management is about determining what should be done by first and foremost setting goals, deciding which events are considered most important and realizing that other activities or events will have to be scheduled around them (prioritizing), making decisions about how much time one allows for certain tasks (time estimation), flexibly adjusting to cater for the unexpected (problem solving), reconsidering priorities and goals on a regular basis (evaluation), and observing patterns and trends in behavior.

There is ongoing debate over exactly what skills and behaviors constitute effective time management.

For example, Shipman identified six principles for effective time management. These principles included being aware of self, setting goals and priorities, structuring time appropriately increasing personal effectiveness and efficiency, scheduling time for events or activity, and scheduling relaxation time [41]. Time management behaviors have more recently been characterized as making lists, organizing, evaluating one's schedule, goal setting, keeping and routinely breaking down tasks and events into simpler parts [10].

An empirical study investigating the effects of time management behavior has identified three broad most important clusters of behaviors. These behaviors include engaging in the mechanics of time management, setting goals and priorities, and having a preference for organization [12]. However, seven time management skills or behaviors can be considered essential to effective time management due to their frequency or repetitive prominence in the literature: (1) time analysis, (2) planning, (3) goal setting, (4) prioritizing, (5) scheduling, (6) organizing, and (7) establishing new and improved time habits[38], [33]; [34], [35]; [11] [13], [14], [15],[36], [37], [42]Although, time management documentation activities such as writing down goals, making lists, and utilizing calendars have been identified by many authors as necessary for effective time management, they tend to cross or fall in line with all seven skill areas mentioned above.

In time management, prioritization which involves determining what one should do by setting goals, deciding which events are the most important and realizing that other activities or events will have to be scheduled around them; three workload categorization dimensions easily come to mind. They include, essential tasks, important tasks and low value tasks. It therefore takes the professionalism and organizational competence of the individual manager to appropriately and accordingly prioritize the given tasks by asking these three fundamental questions; which tasks are most valuable to the organization? Which task does my manager consider most important? And if I cannot complete all the tasks which should I complete?

The need to help staff get organized thereby contributing to the stress reduction, freeing up time to do other activities and increasing work performance and productivity has been more vigorously stressed in recent time than ever.

\section{Organizational effectiveness}

The composition of people who formulate independent business identity for some specific purpose is commonly termed organization, and the process of getting desired outcome within defined resources is referred to as effectiveness. Organizational effectiveness is therefore the notion of how effectual an organization is in accomplishing the results the organization aims 
to generate [39]. It plays a crucially important role in accelerating organizational development [40]. It is said to be the net satisfaction of all constituents or elements in the process of gathering and transforming inputs into output in an efficient manner [42].

Organizational effectiveness is defined as the extent to which an organization, by the use of certain resources, fulfils its objectives or desired goal without depleting its resources and without placing undue strain on its members and/or society. It is the maximum combined utility of the primary constituents

The goal model describes organizational effectiveness by the extent to which an organization attains its goals or objectives. The legitimacy model regards organizational effectiveness focusing on a background evaluation "of component preferences for performance and natural limitations on performance from a purely external environmental perspective" [42].

\section{Theoretical framework}

From the literature gathered for the study, the factors that fundamentally enhance effective time management include: (a) time analysis, (b) planning, (c) goal setting, (d) prioritizing, (e) organizing, (f) scheduling, and (g) establishing new and improved time habits, (h) responsibility and responsibility, (i) delegating and (j) decision making.

\section{Main objective}

The main objective of the study is to analyze the impact of effective time management on organizational effectiveness. The sub-objectives of the study are:

- To explore and determine those factors or indices of time management that impact positively on organizational effectiveness.

- To examine the relationships between time management and organizational effectiveness.

\section{Conceptual framework}

The following constitutes the conceptual framework of the study is:

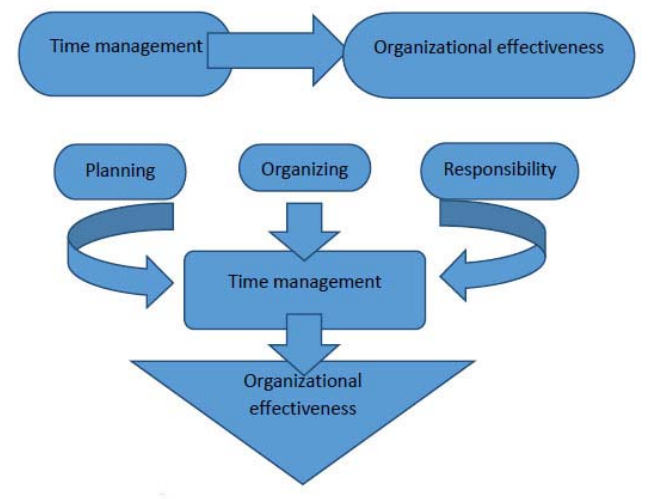

\section{Hypotheses}

Based on the model and literature the study is designed to test the following hypothesis:

- H1: Managerial planning/scheduling has positive impact on organizational effective performance

- H2: Organizing / Prioritization has positive impact on organizational effectiveness/ performance

- H3: There is a positive impact of managerial responsibility \& accountability on organizational effectiveness or performance

- H4: There is a relationship between time management and organizational effectiveness or performance 


\section{Planning and effective organizational performance}

Planning: this involves the formulation of goals or targets and the definition of practical ways or step to be taken to achieving them. When a manager fails to plan, it simply implies, he is planning to fail. A manager's commitment to bridging the gap between potential and actual performance is measured by how much he demonstrates better time management as his lifestyle choice. Planning can be strategic, intermediate or short term.

The study by Adebayo et al proved that, there was a relationship between planning and administrative effectiveness. This shows that planning is pertinent to administrative effectiveness as proper forecasting and planning of educational activities bring a lot of fulfillment and achievement to the administrators [44]. In view of this, Edem, Hendle and Hindle describe planning as a way to improve the use of time [47]. Ajayi and Ayodele observed that "failure to plan gives rise to in- effectiveness, undirected action and waste of resources." [46] The finding equally reflects the minds of Stoner, Freeman and Gulbert [45], they are of the opinion that planning is highly relevant to administrative effectiveness.

\section{Organization / prioritization and organizational effective performance}

Organization/prioritization: Organization means putting all resources you have into plan to achieve personal goal. Some principles for personal organization at work according to L.B. Ojo and D.A. Olaniyan include; setting one's priorities, ensuring that time targets are set for the set priorities, allowing time space for the unexpected, avoid embarking on more than one project at a time, being a productive thinker, separating duties properly, working according to your temperament, avoid developing impossible systems and focusing on results not activity [48].

Adebayo et al (2012) in their study pointed out prioritization as the next predictor of administrative effectiveness with a beta weight of 0.497 (48\%). This implies that if this fundamental principle of time management is not critically considered by administrators, it may pose some difficulties in their administrative work. This was followed by planning with a beta weight of $0.164(16 \%)$, while the least predictor of administrative effectiveness was scheduling with a beta weight of $0.121(12 \%)$. What could be responsible for this is that planning and scheduling are closely related in terms of semantics.

\section{Managerial responsibility / accountability and organizational effectiveness}

Responsibility: the essence of modern management basically borders on responsibility and accountability. It is common to find people passing the buck for every iota of failure or irregularity. According to Winston Churchill the price of greatness is responsibility and the step towards responsibility are: being responsible for who you are, being responsible for what you can do, being responsible for what you have received and being responsible to those that you lead.

Accountability and integrity: It is one thing to have a dream or goal; it is another thing to achieve that same goal. At the end of a specific period, it is important for every responsible manager to measure progress made by taking stock of actual results of his action and compare same with plan.

\section{Time management and organizational effective performance}

The study by Adebayo showed that there was relationship between time management and administrative effectiveness. It gives the impression that administrators need the proper use of time before they can be effective in their various assignments. All the activities being performed by administrators are done within the time hence time management cannot be separated from administrative effectiveness [49]. The following authors share this view Achunine and Irondi [50], Yager [51] and Bulter and Hope [52]time management to them is managing selves and activities and how managers of an organization spend their time on their job determines to a large extent the productivity level of the organization and its effectiveness 
South American Journal of Management

Volume 2, Issue 1, 2016

and efficient performance, profits and survival of the individuals and the organization as a whole.

A similar study conducted by Ahlam Mahmoud El-Shaer, Mahmoud indicated that, there were statistical significant positive correlation post program between head nurses level of knowledge, current use of time management and their perception of effective organizational performance. This result means improving level of head nurses knowledge after program lead to increase current use of time management behaviors and improve their perception to effective organizational performance [52].Consistence with this result the research findings of Ahmed et, al. [53] show that, the nurses' job performance in the organization were affected by their time management in completing the tasks during an event. Furthermore, there was a significant relationship between time management and job performance.

Also, Hamdan Salim Alawamleh and Samar Suleiman Altarawneh, Hamdan et al in their research concluded that the value of the Pearson correlation coefficient was statistically significant at the level of significance less than (0.05), leading to the acceptance of the hypothesis which states: There is a correlation moral statistically significant between the organizational strength and time management at the level of significance $(0.05 \leq p)$ in the branches of the central administration in the Balqa governorate [54].

Adeyinka in examining the relationship between effective time management and high performance in organizations, from the regression result using the SPSS the coefficient of the independent variable is 0.255 which is positive. This means that there is a positive relationship between the organizational high performance and time management. Thus an increase in proper time management will bring about a corresponding increase in the organization performance, all things been equal [55]

In investigating the relationship between students' time management and academic performance in Nigeria's higher institutions Adebayo, the results showed that calculated $\mathrm{r}$ value was 0.798 and the table r-value was 0.195 at 0.05 level of significance. It reflected that r-cal was greater than r-table. Thus, the null hypothesis was rejected and the alternative hypothesis upheld that there is significant relationship between students' time management and their academic performance in higher institutions.

Also, the relationship between prioritization (one of the key indices of time management) and students' academic performance in this study revealed that r-cal was 0.424 and r-table was 0.195 . It showed that $r$-cal was greater than $r$-table at 0.05 level of significance. The null hypothesis was rejected. Therefore, there is a significant relationship between prioritization and students' academic performance in higher institutions [56].

Furthermore, J. F. Adebisi in his research work deduced that performance is measured in relation to time. And effective time management reduces failure. The researcher therefore concludes that there is a direct link between effective time management and performance of business generally [57].

Oleasi and Ayo investigated the effects of three factors: job motivation on performance, time management and effectiveness in one of the industrial states of Nigeria. According to the results obtained from this study, the managers and organizational employees who appropriately used time had better satisfaction in their performance and success in organization level; they obtained a direct positive relation between the mentioned items. In this regards, Classens investigated time management and personal satisfaction in job and found that by time control and management, individuals are more satisfied with their job, which in effect ultimately leads to effectiveness and increase of insight in their performance and organizational effectiveness [58]

According to Elham Saeedi et al the results indicated that, most scholars conducting studies about time management and organizational effectiveness came the conclusion that there is meaningful relation between organizational skills and techniques of time management and organizational effectiveness. That is, better time usage and better management skills will ensure better effectiveness at the organization level, and positive effect on organizational behaviours especially organizational effectiveness could be seen. 


\section{Conclusion}

To survive and prosper in this increasingly competitive global environment, one have to be productive, efficient and effective. Time management is about working actively to create efficiency and effectiveness in a way that makes achieving your targeted results more likely.

Effective time management is a panacea to organizational effectiveness and not a placebo. The results of the review of time management show that the effective use of time has long been recognized as a crucial factor for success in many different fields and many practical techniques have been devised for improving time management[19]

During the study, the researcher deduced that performance or effectiveness is measured in relation to time. And effective time management reduces failure. The researcher therefore concludes that there is a direct link between effective time management and the effective performance of any organization. Good time managers apart from being discipline and responsible, appear to prefer planning, prioritization and organization [59]

Based on the findings of this study, the following empirical conclusions can therefore be drawn: Time management is vital to organizational performance and effectiveness. Therefore, paying more attention to planning, prioritization, delegation of authority, scheduling and ensuring responsibility or accountability while reducing procrastination would improve managerial effectiveness and by extension the realization of organizational goals.

\section{Acknowledgement}

My sincerest and heartfelt gratitude and appreciation goes to Dr. Stephen Kpingpuo, Mr. Martin Bomba-ire D. and my lovely wife, Florence Gamuo for their support and encouragement.

\section{References}

[1]. Alderman L. You can achieve more in a lot less time by following five key steps, 1995.

[2]. Crutsinger C. Thinking smarter: Skills for academic success. Carrollton, TX: Brain works, Inc. Demographics, 1994, 26-8.

[3]. Douglass D. Manage your time manage your work manage yourself. New York, 1980, 271.

[4]. Drucker. Business Management, Mc Graw Hill Publishers, England, 2001.

[5]. Esters I, Castellanos E. Time management Behaviour. Us: paper presented at the Annual meeting of mid-south Educational Research Association, 1998.

[6]. Godbey G, Graefe A. Rapid growth in rushin' Americans American,(2013)

[7]. Gordon JR, Organizational Behaviour, A Diagnostic Approach. Prentice Hall Inc. Edn 6, 1998.

[8]. Hayes-Roth B, Hayes-Roth F. A cognitive model of planning, Cognitive Science, 1979; 3:275 310.

[9]. Jordan C, Cobb N, McCully R. Clinical issues of the dualcareer couples. Social, 1989.

[10]. Kelly WE. No time to worry: the relationship between worry, time structure, and time management. Personality and Individual Differences, 2002, 35, 1119-1126.

[11]. Lakein A. How to get control of your time and your life. New York: Wyden, 1973.

[12]. Macan TH. Time management training: effects on time behaviours, attitudes, and job performance. Journal of Psychology 1996; 130(3):229-236.

[13]. Mackenzie RA. The time trap: How to get more done in less time. New York, NY, 1972.

[14]. Mackenzie RA. New time management methods for you and your staff. Chicago, IL, Dartnell Corporation, 1975.

[15]. Mackenzie RA. The time trap. New York, NY: AMACOM. Management. Bulletin of the Psychonomic Society 1990; 30(1):61-64.

[16]. Money, Vol. 24 No. 10, pp. 37-8.

[17]. Onacken W Jr, Wass DL. Management time: Who's got the monkey? In Winning the Race against Time: How Successful Executives Get More Done in a Day, 1985, 49-54.

[18]. Pollock T. Fifteen common sense ways to manage your time better, Production, 1994, 106(2):10.

[19]. Puffer SM. Task-completion schedules: Determinants and consequences for Robinson, J.P. (1990), “Time squeeze”, American Demographics, 1989; 12.

[20]. Romeo SA. Are you managing your time or is time managing you? Supervision, 1993. 
South American Journal of Management

Volume 2, Issue 1, 2016

[21]. Saiyadain MS. Organizational Behaviour. Tate McGraw -Hill, 2003.

[22]. Schuler RS. Managing stress means managing time. Personnel Journal, 1979.

[23]. Simons DJ, Galotti KM. Everyday planning: An analysis of daily time Boston, MA: Harvard Business Review. Performance. Human Relations, 42, 937-955.

[24]. Slaven G, Totterdell P. Time management training: does it transfer to the workplace? Journal of Managerial Psychology, 1993, 8(1):20-8.

[25]. Sorohan EG. Managing priorities, Training and Development 1995; 49(8):12.

[26]. Soucie D. Proper management of your time. CAHPER Journal 1986; 52(2):36.

[27]Heather, M. 2005. Not time, Stress and the Crisis of modern life. Duoglas and Mcintyre

[28]Reed, D. (2012). What Is Management? http://www. managmentguide.com

[29] North: Y (2004) God's Clock maker; Richard of Wallingford \& the invention of time Oxbow Books

[30]Anand, V. (2007). A study of time management: The correlation between video game usage and academic performance markers. Cyber Psychology \& Behavior, 10(4), 552-559.

[31]Zucas, \& David, H. (2012). Definition of Time Management http://www freetime-management. Tips.com/d.

32]Claessens, B., Eerde, W. \& Rutte, C. A review of the time management literature. Personal Review Vol.36, No 2, 2007: 255-276. www.emeraldinsight

[33]Feeney Jonson, K. (2002). The new elementary teacher's handbook. (2nd ed.). Thousand Oaks, CA: Corwin Press.

[34] Hellsten, L.M, \& Rogers, W. T. (2009). Development and preliminary validation of the Time Management for Exercise Scale. Measurement in Physical Education and Exercise Science, 13, 13-33. [35]Jorde, P. (1982). Avoiding burnout: Strategies for managing time, space, and people in early childhood education. Washington, D.C.: Acropolis Books Ltd.

[36]Adams, G. A., \& Jex, S. M. (1997). Confirmatory factor analysis of the Time Management Behavior Scale. Psychological Reports, 80, 225-226.

[37]Adams, G. A., \& Jex, S. M. (1999). Relationships between time management, control, work family conflict, and strain. Journal of Occupational Health Psychology, 4, (1), 72-77.

[38] Barkas, J. L. (1984). Become more productive and still have fun: Creative time management. Englewood Cliffs, NJ: Prentice-Hall, Inc.

[39]Ahmad, N., Nizan, A. Mohamed, N. \& Wahab, S. The Relationship between Time Management and Job Performance in Event Management. Social and Behavioral Sciences. Vol. 65, 2012: 937-941.

[40]. Hall, B.L. and Hursch, D.E. (1982), an evaluation of the effects of a time management training program on work efficacy. Journal of Organizational Behavior Management, Vol. 3, pp. 73-98.

[41]Shipman, N. (1983). Effective time-management techniques for school administrators. (pp. 174). Englewood Cliffs, N.J. : Prentice-Hall,

[42] Matthew, J., Grawhich, \& Barber, L. K., (2009). Are you Focusing both Employees and Organizational Outcomes. Organizational Health Initiative at Saint Louis University (ohi.slu@edu), 15 .

[43] Zammuto, R. F., (1982). Assessing Organizational Effectiveness, State University of New York Press, Albany, NY.

[44] Adebayo, F. A., \& Omojola, I. (2012). Influence of Time Management on Administrative

Effectiveness in higher institutions in Ekiti State, Nigeria. International Journal of

Educational Research and Technology, 3(1), 52-60.

[45]Lay, C. H., \& Schouwenburg, H. C. (1993). Trait procrastination, time management, and academic behavior. Journal of Social Behavior and Personality, 8, 647-662.

[46] Ajayi, I. A \& Ayodele J. B (2001). Introduction to educational, administration and supervision. Lagos: YPPS.

[47] Edem, D.A. (1987). Introduction to educational administration in Nigeria. Lagos: Spectrum books Limited.

[48] Ojo, L.B. Effective Time Management in Organizational. Panacea or Placebo.2008.http://www.eurojournals.com/ejsr.htm

[49] Adebayo, F. A., \& Omojola, I. (2012). Influence of Time Management on Administrative 
Effectiveness in higher institutions in Ekiti State, Nigeria. International Journal of

Educational Research and Technology, 3(1), 52-60.

[50] Achunine, R. N., \& Irondi, E. O. (1998). Management Administration of secondary education in Nigeria. Lagos: Totan Publishers Limited.

[51]Butler, G. \& Hope T. (2007). Managing your mind, the mental fitness guide, New York: Oxford University press

[52] Ahlam Mahmoud El-Shaer (2015) Impact of Time Management Program on Time Wasters of Head Nurses and Their Perception toward Effective Organizational Performance, Nursing Administration, Faculty of Nursing, Mansoura University. Egypt

[53] Ahmad, N., Nizan, A. Mohamed, N. \& Wahab, S. The Relationship between Time Management and Job Performance in Event Management. Social and Behavioral Sciences. Vol. 65, 2012: 937-941.

[54]Hamdan Salim Alawamleh[a],*; Samar Suleiman Altarawneh[b] (2013)The Impact of Organizational Power Sources on Time Management from the Perspective of Governmental Departments' Managers in Al-Balqa' Governorate. Faculty of Business, AL-Balqaa Applied University, Al-salt, Jordan.

[55]Adeyinka A. Effective time management for high performance in an organization. Business School Degree programme in Business Administration International Business 2012.

[56]ADEBAYO, Florence Aduke (2015) Time Management and Students Academic Performance in Higher Institutions, Nigeria- A Case Study of Ekiti State. 2015, Vol. 3, No. 2

[57] Adebisi, J. Time Management Practices and Its Effect on Business Performance. Canadian Social Science,9(1),2013:165-168 Available from: http://www.cscanada.net/index.php/css/article/

[58] Claessens, B., Eerde, W. \& Rutte, C. A review of the time management literature. Personal Review Vol.36, No 2, 2007: 255-276. www.emeraldinsight.com

[59]Williams, R. L, Verble, J. S., Price, D. E., \& Layne, B. H. (1995). Relationship between time management practices and personality indices and types. Journal of Psychological Type, 34, 36-42. 